\title{
The Inalienable Alien: Giorgio Agamben and the political ontology of Hong Kong
}

\author{
King-Ho Leung
}

\begin{tabular}{|l|l|}
\hline Date of deposit & 23/09/2019 \\
\hline Document version & Author's accepted manuscript \\
\hline Access rights & $\begin{array}{l}\text { C } 2017 \text { Philosophy of Education Society of Australasia. This work } \\
\text { has been made available online in accordance with publisher } \\
\text { policies or with permission. Permission for further reuse of this } \\
\text { content should be sought from the publisher or the rights holder. } \\
\text { This is the author created accepted manuscript following peer } \\
\text { review and may differ slightly from the final published version. }\end{array}$ \\
\hline $\begin{array}{l}\text { Citation for } \\
\text { published version }\end{array}$ & $\begin{array}{l}\text { Leung, K-H. (2019). The Inalienable Alien: Giorgio Agamben and } \\
\text { the political ontology of Hong Kong. Educational Philosophy and } \\
\text { Theory, 51(2), 175-184 }\end{array}$ \\
\hline $\begin{array}{l}\text { Link to published } \\
\text { version }\end{array}$ & \begin{tabular}{l} 
https://doi.org/10.1080/00131857.2017.1310015 \\
\hline
\end{tabular}
\end{tabular}

Full metadata for this item is available in St Andrews Research

Repository at: https://research-repository.st-andrews.ac.uk/

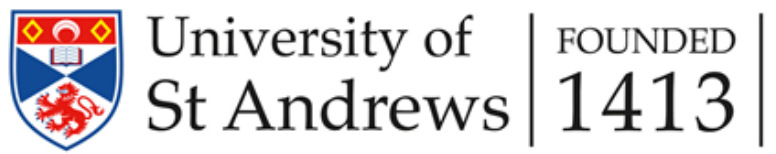




\title{
The Inalienable Alien: \\ Giorgio Agamben and the Political Ontology of Hong Kong
}

\begin{abstract}
Drawing on the work of Giorgio Agamben, this article offers a philosophical interpretation of Hong Kong's recent Umbrella Movement and the city's political identity since its 1997 handover to China. With the constitutional principle of 'one country, two systems' it has held since 1997, Hong Kong has existed as an 'inalienable alien' part of China not dissimilar to that of Agamben's political ontology of the homo sacer's 'inclusive exclusion' in the polis. In addition to highlighting how Agamben's politico-ontological notions such as 'exception' and 'inclusive exclusion' can illuminate the events of the Umbrella Movement, this article focuses particularly on the figure of the student, which many have seen as the symbolic face of the protest campaign. Considering how the student may also be regarded as a figure of 'exception', this article argues that the 'exceptional' role of the student highlights the unique sociopolitical as well as pedagogical aspects of the Umbrella Movement. Finally, comparing Hong Kong's 2014 protests to Agamben's philosophical account of the 1989 Tiananmen protests, this article concludes by suggesting that the Umbrella Movement is not simply a one-off event but fundamentally a manifestation of Hong Kong's continuing political existence since 1997.
\end{abstract}

\section{Keywords \\ Hong Kong; Giorgio Agamben; political philosophy; sovereignty}

In the days leading up to the first anniversary of the Umbrella Movement, director Zhang Xiaoming of the Beijing Central Government's liaison office in Hong Kong released a speech entitled 'A Correct Understanding of the Characteristics of the Political System of Hong Kong.' Zhang (2015) declared that not only does the Central Government in Beijing 'transcend' Hong Kong's executive, legislative and judicial systems, the Beijing-appointed Chief Executive of Hong Kong also has 'a special legal status that transcends the executive, legislature and judiciary.' Since Zhang's controversial speech, the notion of 'transcendence' has been 'at the heart of a battle to define Hong Kong's political system' (Cheung \& $\mathrm{Ng}$, 2015). This article provides a theoretical account of the Umbrella Movement as an expression of Hong Kong's political existence under Chinese sovereignty in light of this controversial notion of 'transcendence', particularly by drawing on the Italian philosopher Giorgio 
Agamben's political ontology of 'exception'—which is defined as 'an element in law that transcends positive law in the form of its suspension' (Agamben, 1998, p. 17, my emphasis). ${ }^{1}$

For Agamben (1998, pp. 17-22), the ontological constitution of 'exception' always involves a paradoxical double-structure which he calls an 'inclusive exclusion'. Drawing on the etymology of the term ex-ceptio, Agamben (2016, p. 144) argues that the 'exception' is that which 'has been "captured outside," which is to say included by means of its exclusion'. This article seeks to highlight how the paradoxical double-structure of 'exception' or 'inclusive exclusion' can be found not only throughout the Umbrella Movement but also in the wider constitutional status and political identity of Hong Kong in its relation to China. ${ }^{2}$ In doing so, this article argues that the Umbrella Movement is not a spontaneous one-off event that emerged out of nowhere, but rather an inevitable outworking or manifestation of Hong Kong's ongoing exceptional political existence as an 'inalienable alien' part of China since the 1997 handover.

This article is divided into four sections. Section one begins with an introduction to the political background of Hong Kong, particularly its 'one country, two systems' constitutional status under Chinese sovereign rule. By way of this introduction, the city's constitutional identity as an 'inalienable alien' is discussed in relation to Agamben's politico-

\footnotetext{
${ }^{1}$ As such, this article focuses on Agamben's critique of sovereignty and biopolitics, as opposed to his more constructive philosophy of life and corresponding vision of 'coming politics' (see Agamben, 2016, especially pp. 195-279).

2 Agamben's notion of 'exception' was previously applied to Hong Kong by Wai-Kit Choi (2007) in two ways: First, Choi (2007, p. 406) described the city as 'an exception that is being both included and excluded by China' because of its non-socialist neo-liberal market economy. Second, the Hong Kong Government is an 'exception' in China with its limited 'sovereign power' and a 'sovereign autonomy' - a legacy of the 'colonialism [that] is persisting in postcolonial Hong Kong' (Choi, 2007, p. 408). Unlike Choi, this article avoids accrediting any notion of 'sovereignty' to Hong Kong-following the language of Hong Kong's constitutional Basic Law, and considers the city's political identity primarily as opposed to Choi's focus on its unique economic position, loosely following Agamben's more recent distinction between the 'political' and the 'economical' (oikonomia) (see Agamben, 2011 and Agamben, 2015). For a critique of Agamben's account of 'economics' and oikonomia, see Milbank (forthcoming).
} 
ontological notion of 'inclusive exclusion'. This is followed by section two, where Hong Kong's political events in late 2014 are considered in light of Agamben's notion of 'the state of exception'. This section demonstrates how 'the state of exception' as well as Agamben's symmetrical conception of the sovereign and the homo sacer may be reflected from both the Beijing regime's assertion of its 'sovereignty' and the reaction from the Hong Kong protestors. Section three then considers how Agamben's double-structure of 'exception' may also be found in the figure of the student, and how the student's 'exceptional' identity highlights unique socio-political as well as pedagogical aspects of the Umbrella Movement. Finally, this article concludes by discussing how Hong Kong's recent developments may resemble or differ from the politico-ontological transformation which Agamben finds in Tiananmen 1989, and how Agamben's work on 'exception' may help one make sense of Hong Kong's political situation and future in the aftermath of the Umbrella Movement.

\section{Hong Kong's Inclusive Exclusion in China}

In 1984, the Sino-British Joint Declaration (hereafter SBJD) was signed by the leaders of China and the United Kingdom on the agreement that Hong Kong would have its 'social and economic systems' and its 'life-style' remaining 'unchanged for 50 years' after the handover in 1997 (SBJD, para. 3). This position became known as the principle of 'one country, two systems' that is stipulated in Hong Kong's constitutional Basic Law:

The socialist system and policies shall not be practised in the Hong Kong Special Administrative Region, and the previous capitalist system and way of life shall remain unchanged for 50 years. (Basic Law, art. 5)

The former British colony is not only permitted to maintain many practices such as its own border-control and currency independently from Mainland China, Hong Kong is also allowed 'to exercise a high degree of autonomy and enjoy executive, legislative and independent 
judicial power, including that of final adjudication' (Basic Law, art. 2) whilst remaining 'an inalienable part of the People's Republic of China' (art. 1, my emphasis).

Although there are clear differences between Hong Kong's liberal-capitalist society and the Mainland's 'socialism with Chinese characteristics', the 'two systems' fundamentally belong to the same 'one country' — ruled under the same sovereign power of Beijing. Given Hong Kong (which became a British colony in 1841) was only 'recovered' in 1997 by the People's Republic regime (established in 1949, more than a century after Hong Kong's 'separation' from China), the city's unification with China is in some regard a late addition: Whilst Hong Kong is 'an inalienable part' of China, its liberal-capitalist system is at the same time socio-politically_and indeed historically_alien to the socialist People's Republic of China. Accordingly, we may say that liberal-capitalist Hong Kong is an 'inalienable alien' part of socialist China-possessing a political existence which very much resembles the politico-ontological 'inclusive exclusion' of the homo sacer's bare life in Agamben's book of the same title.

In Homo Sacer, Agamben (1998) characterises political existence as a doublestructure based on the distinction between $z o \bar{e}$ and bios, two ancient Greek terms for 'life': Zoē refers to 'simple natural life', while bios refers to 'the qualified life of the citizen' (pp. 1$2,124)$. The difference between $z o \bar{e}$ and bios is essentially political, as it concerns the living being's membership or indeed citizenship in the polis: Zoē, the 'simple natural life is excluded from the polis in the strict sense', whereas bios is the classical political life of the human political animal - that which is included in the political activity and membership of polis (p. 2). According to Agamben, the homo sacer, an 'obscure figure of archaic Roman law' who is 'included in the juridical order solely in the form of its exclusion' (p. 8, my emphasis), possesses a 'bare life' that is neither political bios nor natural zo $\bar{e}$, but is situated instead in 'the zone of indistinction in which $z o \bar{e}$ and bios constitute each other in including 
and excluding each other' (p. 90). Thus, the indistinctive 'bare life' of the homo sacer exemplifies the ontology of 'exception' which Agamben (2016, p. 133) sees as underlying Western politics: 'The bare life of the homo sacer is the irreducible hypostasis that appears between $[z o \bar{e}$ and bios] to testify to the impossibility of their identity as much as their distinction.'

While Agamben (1998) argues that Western politics has always been ontologically constituted through 'inclusive exclusion'-'an exclusion (which is simultaneously an inclusion)' (p. 7), he specifically notes that 'the entry of zoe into the sphere of the polis - the politicization of bare life as such — constitutes the decisive event of modernity, and signals a radical transformation of the political-philosophical categories of classical thought' (p. 4). The modern declaration of human rights is the prime example of this as it tries to make all humans automatic bearers of rights by birth (p. 123). All forms of human life, including the natural biological life, are now declared to have civil rights, which previously were only attributed to citizens - zoe is now declared to be bios; all humans are now citizens by natural birth, what Agamben calls 'immediate bearers of sovereignty' (p. 128). But this is only one side of the story: The bearer of rights is in fact a 'sovereign subject... a two-faced being, the bearer both of subjection to sovereign power and of individual liberties' (pp. 124-125). That is to say, whilst all humans appear to be sovereign in the sense of being bearers of rights and individual liberties (protected by the law), they are at the same time all subject to the ruling power of the sovereign (oppressed by the rule of law). In modern political community, humans are simultaneously sovereign and subject, protected and oppressed: They are sovereign through their subjection to the law, protected through being oppressed by the law-paradoxically sovereign through subjection, protected through oppression. Thus, for Agamben, the possession of human rights is always connected (and subjected) to sovereign 
power-perhaps here one may be reminded of the assertion 'sovereign rights are above human rights' often found in Beijing's political rhetoric (see C. Wu, 2010).

Here we find structural or indeed ontological parallels between Hong Kong's constitutional political status and the paradoxical ontology of Agamben's homo sacer figure: Just as the homo sacer is simultaneously included in the polis precisely through its exclusion from the very same political entity, as a former British colony 'recovered' by socialist China under the 'one country, two systems' principle, Hong Kong' is simultaneously included in the socialist political entity precisely through its exclusion from the socialist system. Under the peculiar 'one country, two systems' principle, Hong Kong's political existence under Chinese rule is essentially an 'inclusive exclusion': It is simultaneously included and excluded in China-like the homo sacer, (constitutionally) included solely in the form of its exclusion. Re-phrased in the Basic Law's terminology, Hong Kong is an inalienable part of China by being an alien in China: The city is simultaneously 'inalienable' and 'alien' in China according to its constitutional principle. As such, Hong Kong's political existence under Chinese sovereignty as an 'inalienable alien' that essentially embodies Agamben's politicoontological structure of 'inclusive exclusion' or 'exception'.

\section{Beijing the Sovereign, Hong Kong the homo sacer}

With its 'inclusive exclusion' as an 'inalienable alien', Hong Kong essentially exists as an 'exception' in China, for the city can 'exercise a high degree of autonomy and enjoy executive, legislative and independent judicial power' according to the Basic Law (art. 5). However, the Basic Law is careful to emphasise that Hong Kong's high degree of autonomy does not involve any notion of 'sovereignty'. All mentions of 'sovereignty' in the Basic Law and SBJD refer exclusively to the People's Republic Government in Beijing, and never to Hong Kong's Special Administrative Region Government (SBJD, para. 1; Basic Law, 
preamble). On this note of sovereignty, it should be said that in addition to the homo sacer's inclusive exclusion in the polis, Agamben (1998, p. 84) also applies the structural notion of 'exception' to sovereign power:

the sovereign and homo sacer present two symmetrical figures that have the same structure and are correlative: the sovereign is the one with respect to whom all men are potentially homines sacri, and homo sacer is the one with respect to whom all men act as sovereigns.

Symmetrical to the paradoxical inclusive exclusion of the homo sacer, Agamben (1998, p. 15) notes that the 'paradox of sovereignty consists in the fact the sovereign is, at the same time, outside and inside the juridical order.' As such, the sovereign and the homo sacer exist symmetrically and correlatively as 'the two poles of the sovereign exception' (Agamben, 1998, p. 110).

Drawing on Carl Schmitt's notion of the 'state of exception', Agamben (1998) argues that in the 'exceptional' paradoxical structure of sovereignty:

what is outside is included not simply by means of an interdiction or an internment, but rather by means of the suspension of the juridical order's validity - by letting the juridical order, that is, withdraw from the exception and abandon it. The exception does not subtract itself from the rule; rather, the rule, suspending itself, gives rise to the exception and, maintaining itself in relation to the exception, first constitutes itself as a rule. (p. 18, my emphasis)

In the state of exception, the rule is paradoxically suspended and maintained at the same time: The state of exception is at once both the suspension of the rule and itself the rule; it is the state where 'the exception becomes the rule' (pp. 12, 54-55, 65).

The suspension of law in a 'state of exception' inevitably reminds one of the declaration of 'the state of emergency' - as indeed found in Agamben's own discussions (Agamben 1998, pp. 12, 166-169; 2005, pp. 1-30). During the Umbrella Movement, there have been many speculations on whether the Beijing Government would declare a state of emergency in Hong Kong by invoking Article 18 of the Basic Law. As Fu Hualing, Professor of Law at the University of Hong Kong puts it: 'The invocation of Article 18 and the 
declaration of an emergency in Hong Kong would necessarily mean the suspension of the Basic Law and constitutional rights in Hong Kong, and effectively it signals the end of Hong Kong as we know it' (Fu, 2014, my emphasis). Here we find a clear juridical instance of the paradoxical double-structure of Agamben's 'exception': The invocation of Article 18 would be at once both the invocation and the suspension of the law, the normal rule of law is paradoxically invoked and suspended at the same time-precisely epitomising Agamben's 'state of exception'.

This constitutional possibility of such an exceptional suspension of the law is structurally parallel to Hong Kong's constitutional relation with Beijing's sovereignty. The Basic Law not only states that the Beijing Government can exercise sovereignty over Hong Kong, it also stipulates that the Standing Committee of Beijing's National People's Congress (NPCSC) has the ultimate authority of interpreting the Basic Law. Here again, we find a paradoxical structure of 'exception' in the NPCSC's interpretation of Hong Kong's constitutional Basic Law: Whilst the NPCSC is constitutionally stipulated to have the authority to interpret Hong Kong's laws, the interpretation of the sovereign by NPCSC may at the same time also undermine Hong Kong's constitutionalism and rule of law. In this regard, the NPCSC is at once the entity that authorizes the Basic Law and that which is authorized by the Basic Law to its ultimate interpretation, the 'exception' that is at once constitutionally outside and inside the Basic Law.

While the NPCSC has exercised this 'exceptional' power of interpreting the Basic Law on several occasions since Hong Kong's 1997 handover, ${ }^{3}$ Beijing's assertion of its sovereign power over Hong Kong can be explicitly found in two important documents

\footnotetext{
${ }^{3}$ Most notably the NPCSC's 2016 interpretation of Article 104 of the Basic Law (see Gracie, 2016, and note 9 below) as well as the 1999 interpretation of Article 24 which directly overruled the rulings of the Hong Kong Court of Final Appeal. Hong Kong lawyers have staged a protest march in reaction and judges have also considered resigning after raising
} 
published in the summer of 2014: The 'White Paper' on the 'one country, two systems' principle in Hong Kong released by the Beijing State Council in June 2014 and the NPCSC's August 2014 'Decision’ on universal suffrage and elections in Hong Kong. Legal authorities such as the Hong Kong Bar Association (HKBA) have expressed serious concerns over Hong Kong's judicial independence being 'undermined' by these documents - as stated in their response to the White Paper:

Whilst the NPCSC undoubtedly possesses the power to interpret the Basic Law, the HKBA has consistently maintained that an "NPCSC interpretation" should be rarely and cautiously undertaken. Otherwise there would be a perception of undermining the independence of the judiciary in the eyes of people in Hong Kong, on the Mainland, and in the international community. (HKBA, 2014a, para. 3)

Moreover, the HKBA views that 'the decision of the NPCSC dated $31^{\text {st }}$ August 2014 imposed unreasonable restrictions on civil and political rights [of Hong Kong]' (HKBA, 2014b, para. 4)

Following Agamben's political categories, one may conceive of Beijing's assertion of its sovereignty in these documents—-which the HKBA sees as 'undermining' Hong Kong's judicial system and 'restricting' the people's civil and political rights—as a suspension of normal rule, yielding a new intensified political atmosphere or even political existence for the citizens of Hong Kong and thereby creating a 'state of exception'. This state of exception in Hong Kong is however different from the state of emergency declared in Beijing during the 1989 Tiananmen occupation, in which martial law was enforced. For according to Agamben (2005, p. 4): 'The state of exception is not a special kind of law (like the law of war); rather... it is a suspension of the juridical order itself.' Indeed, in the case of Hong Kong 2014, we do not find any legislation of some 'special kind of law' (such as the martial law in

concerns that the NPCSC's interpretation was undermining Hong Kong's judicial system (Tsoi, 2016). 
Beijing 1989), but instead a structural undermining or even 'suspension' of the juridical order, as we shall see in the following analysis.

The protests and occupation of the streets of Hong Kong, later known as the Umbrella Movement, began less than a month after NPCSC's $31^{\text {st }}$ August decision was issued. During the Movement, there were numerous complaints and reports about the Hong Kong Police Force's abuse of power and excessive use of violence against the peaceful protestors - to the extent that a database was set up by human rights groups to collect visual or written accounts of police violence (Chan, 2014). The most well-known among these cases was one in which seven police officers were themselves arrested after their assault on a protester was filmed by a TV crew (see Forsythe \& Ramzy, 2014). Following Agamben's (1998, p. 57) conception that "in the state of exception, it is impossible to distinguish transgression of the law from execution of the law', one may indeed characterise the Hong Kong Police's own simultaneous 'execution' and 'transgression of the law' as a state of exception.

Moreover, one may find a state of exception not only in the Hong Kong Police's behaviour but also in the protestors' campaign. For Agamben, the state of exception-where 'the exception becomes the rule' - applies not only to a narrow legal definition (in which 'the rule' simply means the 'law') but also to the wider understanding of 'the rule' as social norms and order. Agamben (2005) characterises the state of exception as 'the suspension and overturning of normal legal and social hierarchies' (p. 71), when 'normal social structures can collapse and social functions and roles break down to the point where culturally conditioned behaviors and customs are completely overturned' (p. 65). In the case of the Umbrella Movement the protesters, not only suspended Hong Kong's normal legal and social order through the occupation of major streets in their act of civil disobedience, but also by 
stepping out of their regular social roles - as further discussed in the next section on the figure of the student protestor. ${ }^{4}$

\section{The State of Exception/Education}

Many political theorists have drawn on Agamben's account of the Tiananmen incident to theorise forms of resistance against sovereignty (e.g. Edkins, 2007). Given the parallels between the 2014 Umbrella Movement and the 1989 Tiananmen protests, one may certainly make use of Agamben's notions to analyse Hong Kong's 2014 protests as a resistance movement against Beijing's sovereignty. While the similarities and differences between Tiananmen and Hong Kong are examined in the conclusion, this section specifically focuses on the fact that both of these movements were led by students. The phenomenon of studentled protests is of course not new-one would just have to look at Taiwan's Sunflower movement which had happened six months before the Umbrella Movement. However, there are many interesting aspects in which Hong Kong's student protestors instantiate Agamben's 'indistinctive' paradoxical political ontology that is exemplified in the figure of the homo sacer.

One of the unique things about the Umbrella Movement is that it was led by extremely young student-leaders, most notably Joshua Wong, who appeared on the cover of

\footnotetext{
${ }^{4}$ The stepping-out of social roles in the state of exception applies not only to the side of students and protestors but also Hong Kong's police force, as evident in the police officers' assault on protestors (Forsythe \& Ramzy, 2014). Moreover, the 'exceptional' change in social roles of the police force may be observed in leading police officers' comparison of their experience in the police force to the those of Holocaust victims, controversially given at a mass rally attended by tens of thousands of serving and former police officers in February 2017 against the jailing of the seven police officers who assaulted a protestor (see Leung \& Cheung, 2017). Incidentally, Agamben's prime example of the manifestation of 'bare life' is found in his (in)famous analysis of Nazi concentration camps (Agamben, 1998; 1999). To the extent that Hong Kong police officers (who are usually armed with guns on duty) have the impression that they are Holocaust-like victims, one may say that an exceptional sense of 'bare life' is found on both sides of the Umbrella Movement, throughout the entire city of Hong Kong regardless of people's political views.
} 
Time magazine as 'the face of the protest' (Rauhala \& Beech, 2014). Wong was already a well-known figure in Hong Kong's political scene for leading a massive political rally in 2012 against the Moral and National Education curriculum proposed by the Education Bureau of the Hong Kong Government. In many ways, the groundwork for the mass involvement of the Umbrella Movement was laid by the public attention and participation in this 2012 rally concerning Hong Kong's education policy that was brought into existence primarily by teenage students. Born in 1996, Wong only turned 18 during the first month of the 2014 Umbrella Movement - notably younger than the Tiananmen student leaders who were in their 20s in 1989. Wong's adolescent age and identity constituted another case of 'exception', for adolescence is a 'threshold between childhood and adulthood' (Garcia, 2014, p. 140). The 'threshold' is not only a recurring motif in Agamben's work but more importantly a paradigmatic structure of exception: It is the structure at which 'two spheres are joined in becoming indeterminate', like how the homo sacer's bare life exists in a 'zone of indistinction' (Agamben, 1998, p. 90).

Follow Agamben's (1998, p. 181) conception of bare life as the 'threshold of articulation between nature and culture, zoe and bios,' one can likewise note that 'Adolescence is the gap or contact between our cultural customs and nature' (Garcia, 2014, p. 407). ${ }^{5}$ Adolescence is in this respect not dissimilar to the homo sacer's bare life: Like the inclusive exclusion of the homo sacer in the polis, the adolescent is included in adulthood by a simultaneous exclusion of being too young to be regarded as fully adult, and yet too old to be properly included among children. ${ }^{6}$ All in all, it is no surprise that Time magazine's cover

\footnotetext{
${ }^{5}$ While 'adolescence' is not specifically theorised as an 'indistinctive' threshold, Agamben (2007, p. 15) speaks of 'Genius' as 'a part that is forever immature, infinitely adolescent, and hesitant to cross the threshold of any individuation.' For an educational theorisation of this, see Lewis (2013, p. 118).

${ }^{6}$ This 'suspended' mode of being may be further observed in Wong's judicial review application in the aftermath of the Umbrella Movement to challenge the minimum age of Hong Kong Legislative Council candidacy: Wong, aged 19 at the time of the judicial review
} 
story on Wong remarks that: 'If Wong is wary of adulthood, his beloved home, Hong Kong, is also suspended in adolescence' (Rauhala \& Beech, 2014, my emphasis), and that it is the student that is regarded as the very 'face' of Hong Kong's protest.

The 'suspended' figure of the student — 'the political figure par excellence' according to Tyson Lewis's (2013, p. 13) study on Agamben and education-may offer us some insight into how the Umbrella Movement may be understood as an 'exceptional' education experience for Hong Kong. Just as Joshua Wong, who admitted that he was 'never a top student' by traditional standards, has been regarded as an outstanding or indeed 'exceptional' student during and after the Umbrella Movement (Lee, 2014), Wong's student-led protest campaign may likewise be regarded as an 'exceptional' education experience: In addition to young protestors doing their homework and academics giving lectures at the 'Mobile Democracy Classrooms' on the occupied streets, a number of school teachers also brought their classes on field trips to the protest sites as well as directly participating in the Movement under the student protestors' leadership (Barber, 2014; Leong, 2015).

While many university and school classes were indeed suspended during the protests, the protest campaign itself in turn paradoxically became a novel educational experience for many in its suspension of normal education. To paraphrase Agamben's formulation of the state of exception, the Umbrella Movement was at once both the suspension of normal education and itself an educational experience. During the 2014 protests, we not only find the occupied streets of Hong Kong becoming new sites of education-a literal deterritorialization of the classroom, but also a reversal in Hong Kong's traditional (especially Confucian) hierarchical relation between teachers and students. With students in the frontline and leadership of the Movement, many professional teachers found themselves being directed, instructed or indeed educated by the full-time students on the streets of Hong Kong in 2014.

application, was precisely 'suspended' between Hong Kong's current minimum voting age of 
In the Umbrella Movement, the student leaders became, to invoke Paulo Freire's (2005, p. 72) phrase, 'simultaneously teachers and students': They were at once students receiving fulltime education and teachers educating the protest participants in a novel educational 'state of exception'?

\section{Tanks and Tiananmen}

With the paradoxical indistinctive identity of the protesting students as well as the suspension of traditional societal roles and social order, it may indeed be said that 'the Umbrella Movement has given rise to a new political mass, one that incorporates people of all races, demographics and backgrounds, people with all sorts of different and varied connections to the city' (R. Wu, 2014, p. 92). This perhaps hyperbolic account of Hong Kong's 'new political mass' is not dissimilar to Agamben's (1993) ontology of 'whatever beings' in his analysis of Tiananmen 1989, where he finds a political community that is not constituted through inclusions and exclusions, but 'the politics of whatever singularity' where 'singularities form a community without affirming an identity, that humans co-belong without any representable condition of belonging' (pp. 85-86). ${ }^{8}$ For Agamben, 'What was most striking about the demonstrations of the [1989] Chinese May, in fact, was the relative absence of specific contents in their demands' (p. 85). It is precisely this lack of clear demands which unified the protesters into forming 'a community without affirming an identity' (p. 86). One may say the same thing about the Hong Kong protests, as Joshua Wong stated in an interview in the aftermath of the campaign that the Umbrella Movement 'had no

18 and the legally required age of 21 to run for the elections.

${ }^{7}$ See Lewis's (2013, pp. 102-104) discussion of Freire in relation to Agamben's state of exception.

${ }^{8}$ Note that the section on the 'whatever' ontology of Tiananmen in The Coming Community is the only place where the Agamben (1993, pp. 86-87) explicitly discusses the homo sacer in the whole book (which predates the beginning of his Homo Sacer project series by a few years). 
clear goals' (Liu, 2015) — which one may say gave rise to the 'new political mass' of a complete political co-belonging akin to Agamben's 'whatever beings' of Tiananmen 1989.

Although many similarities between the Umbrella Movement to the Tiananmen protests were highlighted by the media, the Hong Kong protests had a very different ending from the Tiananmen occupation 25 years ago. ${ }^{9}$ In the concluding sentence of his analysis of Tiananmen, Agamben remarks that whenever the political ontology of 'whatever beings' is realised, where 'all identity and every condition of belonging' (constituted through inclusions and exclusions) are rejected, 'there will be a Tiananmen, and, sooner or later, the tanks will appear' (Agamben, 1993, p. 87, my emphasis). For Agamben, the tanks will appear as the sovereign power of the State will always seek to reinforce the existing exceptionality of its sovereignty (Edkins, 2007, pp. 84-85).

While tanks did not appear on the streets of Hong Kong in 2014, one may remember the historical moment when tanks did appear on the streets of Hong Kong in 1997-as China's People's Liberation Army vehicles entered the city at dawn the morning of the handover. Accordingly, one might hypothesise that the politico-ontological 'exceptionalisation' of Hong Kong did not take place in 2014, but instead in 1997. As in Agamben's analysis of Tiananmen, tanks precisely appeared to reinforce the 'transcendent' structure of exception that essentially underlies the politics of sovereignty. Accordingly, just as the tanks have already appeared in Hong Kong - in 1997, we can see how the politicoontological 'exceptionalisation' of Hong Kong has already taken place. It was in 1997 that Hong Kong assumed a homo sacer-like 'inclusive exclusion' political existence, constitutionally becoming an 'inalienable alien' part of China.

\footnotetext{
9 One may also compare Hong Kong's 'Mobile Democracy Classroom' to Tiananmen's 'Democracy University' that was set up just hours before the military intervention on 3 June 1989.
} 
Thus, the Umbrella Movement-described by some as 'the politicisation of the apolitical city' (Lu, 2014) — is in fact more of an intensification or expression of the post1997 politicisation of Hong Kong. The Movement is not so much a historical 'turning point' itself, but fundamentally an outcome of the true turning point of Hong Kong's political existence - a turning point of not only Hong Kong but wider Chinese history: The 1997 handover. The 1997 transfer from British to Chinese sovereignty marked the true transformation of Hong Kong's political ontology, assuming its new political existence as an 'inalienable alien' part of China under the 'one country, two systems' constitutional principle. Here we may reconceive Agamben's characterisation of 'the decisive event' of 'the entry of $z o \bar{e}$ into the sphere of the polis' with China as the polis and Hong Kong as the $z o \bar{e}$ : The decisive event for Hong Kong and the radical transformation of its political identity is not the Umbrella Movement, but instead the entry of Hong Kong into the sphere of the Chinese political space in 1997 (cf. Agamben, 1998, p. 4).

\section{Conclusion}

This article has highlighted various ways in which structural patterns of Agamben's ‘exception' can be observed repeatedly in many aspects of Hong Kong's political situationthe Umbrella Movement's occurrence is just one instance of them. Whilst the Movement can indeed be called an 'exceptional' event, Agamben's work reminds us that a state of exception is essentially one in which 'the exception becomes the rule'. The Umbrella Movement thus must not be regarded as a 'one-off' event or exception, it should instead be thought of as in some sense 'the rule' - the paradigm through which Hong Kong's wider political situation could be understood. The campaign was not the creation but the expression or manifestation of the state of exception that has been unfolding in Hong Kong's political climate since it became an 'inalienable alien' under Chinese rule in 1997-as we find in the ongoing 
constitutional and political disputes over 'exception' and 'transcendence' in relation to Hong Kong's political situation in the aftermath of the Umbrella Movement, most notably the NPCSC's recent 'interpretation' of Article 104 of the Basic Law alongside the judicial review filed by the Hong Kong government to disqualify a number of democratically-elected opposition lawmakers in late 2016, which has been regarded by some as an unprecedented challenge to Hong Kong's judicial and legislative systems (see Gracie, 2016; Tsoi, 2016). ${ }^{10}$

The Umbrella Movement can thus be said to be the 'realisation' of the city's political ontology in both senses of the word: It is not only the moment in which the people of Hong Kong become aware of their political existence-seen as the "politicisation of the apolitical city', it is also the instance where Hong Kong's exceptional political ontology is represented materially. As such, the Umbrella Movement can be said to be a 'conclusion' of Hong Kong's accumulating political intensity since its 1997 entry-inclusive exclusion-in the Chinese political space, but it is also simultaneously an 'inconclusive' event. Having become the rule, Hong Kong's state of exception is an ongoing politico-ontological phenomenon since 1997. It is not merely an 'exceptional' one-off event; it is in fact 'the rule' or indeed 'norm' of Hong Kong's political existence. In conclusion, one might say that the 2014 event is an 'inconclusive conclusion' of Hong Kong's politico-ontological 'exceptionalisation'. The Umbrella Movement is not the beginning of Hong Kong's political state of exception. Neither is it the end.

\footnotetext{
${ }^{10}$ Another challenge to Hong Kong's executive and judicial systems - as well as to the constitutional independence of the city's own border-control-is the alleged abduction of the British-Hong Kong bookseller Lee Bo by Mainland Chinese law-enforcement agents from Hong Kong in December 2015 (see Phillips, 2016).
} 


\section{References}

Agamben, G. (1993). The Coming Community. (M. Hardt, Trans.). Minneapolis, MN: University of Minnesota Press.

Agamben, G. (1998). Homo Sacer: Sovereign Power and Bare Life. (D. Heller-Roazen, Trans.). Stanford: Stanford University Press.

Agamben, G. (1999). Remnants of Auschwitz: The Witness and the Archive. (D. HellerRoazen, Trans.). New York: Zone Books.

Agamben, G. (2005). State of Exception. (K. Attell, Trans.). Chicago: Chicago University Press.

Agamben, G. (2007). Profanations. (J. Fort, Trans.). New York: Zone Books.

Agamben, G. (2011). The Kingdom and the Glory: For a Theological Genealogy of Economy and Government. (L. Chiesa, Trans.). Stanford: Stanford University Press.

Agamben, G. (2015). Stasis: Civil War as a Political Paradigm. (N. Heron, Trans.). Stanford: Stanford University Press.

Agamben, G. (2016). The Use of Bodies. (A. Kotsko, Trans.). Stanford: Stanford University Press.

Barber, E. (2014, October 14). Hong Kong Student Protesters Prepare for Midterms. Time. Retrieved from http://time.com/3503870/occupy-central-hong-kong-student-protestersmidterms-exams-class-boycott-democracy/

Basic Law of the Hong Kong Special Administrative Region of the People's Republic of China. Retrieved from http://www.basiclaw.gov.hk/en/basiclawtext

Chan, S. (2014, December 17). Hong Kong rights groups set up database on Occupy police violence complaints. South China Morning Post. Retrieved from http://www.scmp.com/news/hong-kong/article/1663355/hong-kong-rights-groups-setdatabase-occupy-police-violence

Cheung, G., \& Ng, J. (2015, September 23). Transcendent: the word at the heart of a battle to define Hong Kong's political system. South China Morning Post. Retrieved from http://www.scmp.com/news/hong-kong/politics/article/1860241/transcendent-wordheart-battle-define-hong-kongs-political

Choi, W. K. (2007). (Post)coloniality as a Chinese state of exception. Postcolonial Studies, 10(4), 391-411.

Edkins, J. (2007). Whatever Politics. In M. Calarco \& S. DeCaroli (Eds.), Sovereignty and Life: Essays on Giorgio Agamben (pp. 70-91). Stanford: Stanford University Press.

Forsythe, M., \& Ramzy, A. (2014, November 26). 7 Officers Arrested in Beating of a Protester in Hong Kong. The New York Times. Retrieved from http://www.nytimes.com/2014/11/27/world/asia/hong-kong-protests-mongkok.html?_r=0

Freire, P. (2005). Pedagogy of the Oppressed. (M. B. Ramos, Trans.). New York; London: Continuum.

Fu, H. L. (2014, October 5). When Can the People's Liberation Army Intervene in Hong 
Kong's Umbrella Revolution? HKU Legal Scholarship Blog. Retrieved from http://researchblog.law.hku.hk/2014/10/when-can-peoples-liberation-army.html

Garcia, T. (2014). Form and Object. (M. A. Ohm \& J. Cogburn, Trans.). Edinburgh: Edinburgh University Press.

Gracie, C. (2016, November 7). China blocks Hong Kong lawmakers in a reminder of who is in charge. $B B C$ News. Retrieved from http://www.bbc.com/news/world-asia-china37893947

Hong Kong Bar Association (HKBA). (2014a, June 11). Response of the Hong Kong Bar Association on the White Paper on the Practice of "One Country, Two Systems" Policy. Retrieved from http://www.hkba.org/whatsnew/misc/White_Paper_Response_eng.pdf

Hong Kong Bar Association (HKBA). (2014b, October 28). Statement of Hong Kong Bar Association in respect of "Mass Defiance of Court Orders." Retrieved from http://hkba.org/sites/default/files/20141028\%20$\% 20$ Statement $\% 20$ of $\% 20$ Hong $\% 20$ Kong $\% 20$ Bar $\% 20$ Association $\% 20$ Relating $\% 20$ to $\%$ 20Mass $\% 20$ Defiance $\% 20$ of $\% 20$ Court $\% 20$ Orders $\% 20 \% 28$ Eng $\% 29 \% 20$ \%20FINAL1.pdf

Lee, E. (2014, August 13). 'I was never a top student': Scholarism leader Joshua Wong. South China Morning Post. Retrieved from http://www.scmp.com/news/hongkong/article/1572475/scholarism-leader-accepted-politics-programme-open-university

Leong, M. (2015, October 21). Reflections From a Revolution. The Chronicle of Higher Education. Retrieved from http://chronicle.com/interactives/umbrella_revolution

Leung, C. \& Cheung, E. (2017, February 24). Hong Kong police chiefs rush to repair damage over remarks comparing jailed officers to Jews persecuted by Nazis. South China Morning Post. Retrieved from http://www.scmp.com/news/hong-kong/lawcrime/article/2073699/not-appropriate-compare-convicted-hong-kong-police-officers

Lewis, T. E. (2013). On Study: Giorgio Agamben and educational potentiality. Abingon; New York: Routledge.

Liu, J. (2015, August 2). Joshua Wong: 'We had no clear goals' in Hong Kong protests. $B B C$ News. Retrieved from http://www.bbc.co.uk/news/blogs-china-blog-33729241

Lu, R. (2014, September 28). A turning point in the fight for Hong Kong. Foreign Policy. Retrieved from http://foreignpolicy. com/2014/09/28/a-turning-point-in-the-fight-forhong-kong/

Milbank, J. (2017). Oikonomia leaves home: Theology, politics and governance in the history of the west. Telos, 178, 77-99.

NPC decision on Hong Kong's constitutional development. Retrieved from http://www.fmcoprc.gov.hk/eng/syzx/tyflsw/t944943.htm

Phillips, T. (2016, January 3). Hong Kong politicians call for Beijing to explain booksellers' 'abductions'. The Guardian. Retrieved from https://www.theguardian.com/world/2016/jan/03/hong-kong-politicians-call-beijingcomment-lee-po-editor-abduction

Practice of the 'One Country, Two Systems' Policy in Hong Kong (2014, June 10). Also known as the 'White Paper'. Retrieved from http://www.fmcoprc.gov.hk/eng/xwdt/gsxw/t1164057.htm 
Rauhala, E., \& Beech, H. (2014, October 8). The Voice of a Generation. Time. Retrieved from http://time.com/3482556/hong-kong-protest-teenagers/

Sino-British Joint Declaration on the Question of Hong Kong (SBJD). Retrieved from http://www.cmab.gov.hk/en/issues/jd2.htm

Tsoi, G. (2016, November 7). What is Hong Kong's political controversy about?. BBC News. Retreved from http://www.bbc.com/news/world-asia-china-37893070

Wu, C. (2010). Sovereignty, Human Rights, and Responsibility: Changes in China's Response to International Humanitarian Crises. Journal of Chinese Political Science, 15(1), 71-97.

Wu, R. (2014). The Rebirth of Hong Kong. Syndicate: A New Forum for Theology, 1(4), 8792.

Zhang, X. (2015, October 16). Zhang Xiaoming's controversial speech on Hong Kong governance. South China Morning Post. Retrieved from http://www.scmp.com/news/hong-kong/politics/article/1858484/zhang-xiaomingscontroversial-speech-hong-kong-governance 